\title{
EL VACÍO COMO FENÓMENO ESTÉTICO-RELIGIOSO EN LA OBRA DE JOSÉ ÁNGEL VALENTE
}

\author{
Guillermo Aguirre-Martínez \\ Ruhr-Universität Bochum - Universität Münster \\ guillermo-aguirre@hotmail.com
}

\begin{abstract}
RESUMEN / ABSTRACT
Un espacio carente de dimensiones y de contenido podrá observarse a modo de límite primero y último en la poesía de José Ángel Valente. De este modo, a un vacío inicial del que surgirá la creación poética, le corresponderá, en su otro extremo, un margen igualmente carente de medida y de sustancia al que se arrojará la palabra poética en su búsqueda de un orden trascendental. El vacío - la nada, lo indefinido-, se constituirá como polo de atracción de una poesía cuyas formalizaciones participan de una serie de metamorfosis que, a modo de escala, permiten el desplazamiento de las imágenes entre los dos límites que componen el espacio creativo del autor. Las siguientes páginas estudiarán la función y el valor de este espacio libre de formas en la obra lírica de José Ángel Valente.
\end{abstract}

Palabras Clave: José Ángel Valente, poesía, mística, vacío, Ursatz.

This study focuses on the role and value of void and silence in José Ángel Valente's poetry. In this light, the void can be seen as the origin and end of Valente's work. On the one hand, the void signals the source from which the poetic word grows. On the other, it refers to the kind of emptiness characteristic of a sacred space in a transcendental order. In this way, the notion of void, silence, or nothingness can be viewed as a double pole of attraction whose boundaries reflect the movement of the poetic word. Considering its spiritual nature, this word undergoes a series of metamorphoses between these two poles.

KEY WORDS: José Ángel Valente, poetry, mysticism, void, Ursatz. 


\section{INTRODUCCIÓN}

El vacío, ya como espacio no alcanzado, ya como Ursatz previo al fenómeno poético, desconocido e indescifrable aunque presentido dada la gravedad que es capaz de ejercer sobre lo expresado, se corresponde con uno de los elementos más claramente definitorios de la obra de José Ángel Valente. Este vacío, como preexistencia anterior a toda formación, se presentará a modo de energía sin materializar, fenómeno asimilable a la voluntad pura de Schopenhauer. La obra de arte, como representación de esa voluntad, dará expresión a una fuerza original cuya esencia no coincide con el yo del poeta, pues el acto de creación atañe a algo anterior a su individualidad. Este proceso puede observarse como una negación del yo -tal y como lo comprende el propio Valente-, llegando el creador "a vaciarse de sí mismo, a desposeerse” (Peinado Elliot 322). De acuerdo con Jung, se trata de un proceso en el que lo manifestado preexiste al sujeto, pues las obras

se imponen literalmente al autor [...]. Su conciencia contempla el fenómeno atónita y vacía, mientras se ve inundada por un torrente de ideas e imágenes que su intención jamás ha creado y que su voluntad jamás habría querido producir. Con renuencia tendrá que reconocer que en todo ello habla su sí-mismo, que su naturaleza más íntima se revela a sí misma y proclama en alta voz lo que él jamás le habría confiado a su lengua. Sólo puede obedecer y seguir este impulso [...]. Es consciente de que se sitúa por debajo de su obra o, al menos, a su lado, como una segunda persona que se viera abocada a girar en la órbita de una voluntad ajena a ella (64-65).

Esta última voluntad es la que dominará, desde el fondo, el proceso de gestación de la obra de arte, no tanto por el hecho de apoderarse de la misma, sino por la desaparición de toda obstrucción que restrinja su libre nacimiento.

El presente fenómeno vendrá acompañado de una actitud de espera encaminada a borrar todo condicionamiento ajeno al impulso espiritual de la obra, una actitud que, en el caso de Valente, cobrará solidez a medida que su poesía prescinda más y más de los designios tomados por una conciencia comprendida como una carga y no ya como un elemento vivificante de su poesía. Según menciona el propio autor,

el creador tiene que ir acostumbrándose a la aniquilación del "yo" que es el proceso de purificación espiritual. Toda creación literaria auténtica, poética, por utilizar la palabra poética en su sentido más 
amplio, tiene que ir acompañada de una experiencia espiritual, si no, no vale de nada. Eso lleva a una aniquilación del "yo" y probablemente a una visión de la nada, aunque positiva (Valente y Fernández Quesada 147).

Lo vacío no será entendido como una carencia sino como un indicio de energía creativa. Este vacío parecerá, desde luego, ausente desde un punto de vista sensorial, pero no así desde uno espiritual, al permanecer totalmente implicado en el engendramiento de la obra. El silencio o la nada se corresponden, de este modo, con un estadio neutro del que todo parte y al que la realización estética, comprendida como autoconocimiento, tratará de retornar.

Como vamos viendo, la actitud del poeta se va a volver, en un primer momento del acto de creación, pasiva, tendente a desaparecer, a no entorpecer el proceso de búsqueda de la voluntad vacía ${ }^{1}$, correspondiente con el sustrato primero de la poesía. Ésta, dada su libertad intrínseca, no servirá a nadie salvo a sí misma, siendo creadora de sus propias reglas y formalizaciones. El vacío se muestra, por todo ello, como origen y como final; origen no consciente para el creador y final en tanto que tendencia inagotable de una búsqueda cuyo objeto último, de haberlo, no alcanzará a ser designado por la palabra del poeta.

\section{ABISMO Y RELIGIÓN}

En aquellos momentos en que el poeta alcanza la plenitud cósmica sin alejarse del universo inmanente, podremos observar cómo el sustrato espiritual quedará concentrado dentro de lo designado ${ }^{2}$. Esto solo ocurrirá en la poesía del autor con la aparición de símbolos completos (árbol, cruz, hombre, etc.) o con la

\footnotetext{
Esta voluntad la define Schopenhauer como "lo que no se ha de explicar por otra cosa sino que más bien explica todo lo demás [...]. Es la esencia del mundo y el núcleo de todos los fenómenos" (335). Por ello, no siendo propiamente nada, originará todo fenómeno, toda representación.

Cabe mencionar el comentario al respecto que Luigi Pareyson realiza en sus Conversaciones de estética:

lo bello natural se puede explicar con la teoría de la "normatividad", en cuanto que la imagen que el espectador saca de las cosas es el resultado, incluso la culminación, de un proceso de formación. La imagen de una cosa es la cosa misma tal y como es interpretada por el que la contempla, y el proceso de interpretación es un proceso
} 
consecución de estadios de ingravidez ya hacia el final de su obra. Por otra parte, una orientación excéntrica del espíritu comprenderá la palabra como simple residuo de un fenómeno más amplio de imposible expresión, indicio lejano del cuerpo de un Dios inaprensible desde un orden estético. En este caso, lo expresable no convergerá de lleno con la materia que lo anima, abriéndose una brecha entre la representación y su significado último.

Al tiempo que esto acontece, un abismo se abrirá entre creación y creador, saliendo a la superficie aquella tendencia mística natural en Valente que le lleva a buscar, por concentración y transparencia, a la divinidad desde un plano diurno, meta imposible pues se pretende alcanzar mediante un acercamiento sensitivo-racional aquello que demanda una absoluta certeza interior, espiritual. Nos situamos, por tanto, ante un deseo de acceder a la inconsciencia desde la conciencia, a la fe desde el escepticismo, pues el artista querrá hacer acto de aparición en su propio proceso creador, descorriendo el velo de maya desde la luz de la conciencia y, consecuentemente, quedando condenado a levantar velo tras velo en un proceso sin fin dado que cuanto se requerirá realmente no es una acción, sino la adquisición de un estado de visión no deudor de un esfuerzo del intelecto sino de un fenómeno religioso; es decir, la consecución de un estado de contemplación. Será en estos momentos de alejamiento de lo real cuando la palabra de Valente pierda su fuerza más profunda y expresiva, aquella que le es provista por la carnalidad propia de la materia.

Puesto que en este punto el poeta desconfiará de la manifestación, tratará de evadirse del marco de lo real al suponer que hay diferencia de grado ontológico entre el adentro y el afuera, siendo su técnica usual el alcanzar una transparencia máxima que, dejando el velo divino en su mínima expresión, permita observar el flujo espiritual interno que habita la voz. Llegado el caso, esta técnica, dado que no es fruto sino de un hondo escepticismo, invitará a la observación de la propia duda interior, una nada tornada ahora en expresión de una carencia de espíritu, de un espíritu de negación. Por todo ello, será precisamente en los momentos en que el velo se haga más diáfano, más tenue, cuando su poesía se torne totalmente gris, perdiendo en formas, en matices, quedando desprovista de la enorme densidad adquirida en otros lugares de su lírica como, por ejemplo, en el grávido y genesíaco Material memoria, donde asistimos a una poesía vasta, enérgica y no necesariamente menos habitada 
por la divinidad. De este modo, será precisamente en los momentos en que el poeta se aproxime con mayor cercanía a los abismos místicos, cuando mayor sea su desgarro interior, mayor su desamparo.

La comprensión del proceso creador que vamos comentando parte de una noción de libre necesidad en la que forma y voluntad buscan su mutua adecuación, siendo la expresión un todo en el que unos no alcanzarán a ver más que lo externo privado de su interior, mientras que otros, atentos tanto a lo sensible como a lo no fenoménico, atisbarán la hermosura radiante del espíritu. Pese a esta intención de completitud, Valente solo podrá disfrutar en contados momentos de la convergencia entre expresión y objeto último de su poesía, pues tenderá a priorizar la parte frente a la totalidad, prefigurando con este planteamiento el fracaso de su búsqueda mística en la medida en que ésta solo resulta afianzada desde la honda convicción en el todo abarcador.

A la hora de explicar esta tendencia inacabable, Valente se verá obligado a emplear términos propios de una mística negativa:

nada dice, en efecto, esta voz que no sea su propia aparición. Ni la palabra nada dice en realidad, pues es sólo -en lo alto- repentina señal, invitación al fondo. De ahí que el poema se sitúe en un eje que no reconoce, en rigor, más valores que la altura y la profundidad. Por eso la forma interna (y la forma tipográfica) del poema es aquí, tan acusadamente, la vertical (Obras Completas II 1334).

Como leemos, el conflicto no residirá en el proceso creador ni en la dirección de la búsqueda, sino en el interior de la propia palabra, participante de una vacuidad de orden esencial. Nos situamos ante una voz profundamente nihilista sostenida por una parte desde la conciencia del autor y, a su vez, desde una necesidad de Dios. El presente aspecto resulta extrapolable a la querencia emocional del poeta por habitar una materia fecundante $y$, a la vez, por su necesidad racional de ascender hacia una divinidad de orden trascendente.

Observamos perfectamente en las anteriores palabras de Valente la desconfianza mostrada hacia una expresión de honda densidad espiritual pero, sorprendentemente, cerrada a un plano trascendente. El creador participará de una natural inclinación a la búsqueda del absoluto; búsqueda asociada, desde luego, con su tendencia a rechazar un mundo constreñido por lo perteneciente exclusivamente al orden de lo mensurable. Por otra parte, el espacio al que se pretende acceder se aproxima -según qué etapa de su trayectoria y según qué logros adquiridos- ya a un Dios cristiano, ya a una divinidad interior, ya a una divinidad con tintes panteístas-; en ningún caso, sin embargo, Valente 
se pronunciará sobre el tema del alma individual si no es, por lo general, para lamentar el hecho de no ser capaz de dar con su naturaleza eterna. El acercamiento a diferentes doctrinas resultará asiduo y sus diferentes huellas se podrán observar a lo largo de una obra altamente espiritual, no pudiendo apreciarse, en cualquier caso, una conclusión definida -salvo por negaciónsobre el sentido último de ese mismo espíritu, quedando en consecuencia ante nosotros una lírica de tono existencial. Pese a ello, será precisamente el lenguaje de la mística el que enseñe a nuestro autor a pulir una poesía cada vez más severa, más sobria, más densa y concentrada. Valente no es, según vemos, un místico en sentido estricto. En palabras de Saúl Yurkievich, según recuerda Virginia Trueba:

"Presiente pero no presencia [...] La poesía de Valente escribe dios con minúscula”. Desde este punto de vista con lo que sí entronca la (meta) poesía de Valente es con una modernidad en la que la paradoja mística subyace pero transformada. El silencio de la palabra mística (o su no tener sentido), debido a que aquello de lo que se habla (Dios) no posee sentido por ser el Referente en sí, se ha trasladado a esa modernidad negadora de la trascendencia pero mitificadora de la inmanencia: la palabra poética también trata de significar el no-sentido del Referente, sólo que ahora ese Referente no está en el más allá sino en el más acá de la palabra [...] Valente no es, pues, un místico en sentido estricto. Es un poeta empeñado hasta el final en una nostalgia que es también, aunque parezca paradoja, una utopía. Este es el sentido de su presente a lo largo del tiempo (Trueba 175).

El poeta buscará desaforadamente a la divinidad a través de la escritura, logrando fugitivas iluminaciones mantenidas por unos breves instantes poco antes de volver a emprender su exasperante búsqueda ante la imposibilidad de alcanzar una certeza. En lo referente a estas iluminaciones, cabrá comprenderlas ya como intuiciones puras pero pasajeras, ya como, según refiere Gamoneda de manera un tanto desacertada, "una tensión alucinatoria que hace perceptible y sensible lo que no existe fuera de esta alucinación lúcida" (21). En cualquier caso, aquello que nos interesará a nosotros será el modo en que quede representado este hecho en el conjunto de su poesía, es decir, como un fenómeno puntual, pues todo aquello no se manifiesta enteramente en el desarrollo, pierde vigencia y valor -no necesariamente veracidad- en sus extremos: la huella dejada por nuestro poeta será así decididamente desgarrada y carente de certezas. 
De acuerdo con lo que vamos observando, parece evidente que el lenguaje, sin ser considerado capaz de alcanzar satisfactoriamente unas lindes metafísicas, sí se mostrará apto para orientarnos hacia el objeto poético ulterior aun por aproximación, ya sea reduciendo el círculo lógico hasta que quede tan solo un vacío convergente con la idea de absoluto, ya apuntando hacia aspectos palpables cuya reverberación se acerque, como por ondas, hacia dicha esencia. En cualquier caso, como sabemos, el signo que se le atribuya al absoluto devendrá de una espiritualidad ajena a todo aquello que el lenguaje puede precisar de no venir precedido de un convencimiento interno. En este aspecto, según menciona Rudolf Otto, "la propia mística no cree que (el predicado esencial) sea totalmente incomprensible, aun cuando lo llama árreton (lo inefable, indefinible); pues entonces la mística debería consistir en el silencio. Pero precisamente ha sido la mística verbosa en extremo" (11).

Habría que diferenciar, desde nuestro planteamiento, al místico convencido de cuanto, sin ser capaz, desea expresar -un místico que intenta derribar toda barrera, todo límite que le impida alcanzar la esencia de Dios; misticismo que más allá de lograrse o no aproximar a su empresa denotará una religiosidad arraigada al sujeto- de aquel otro místico propiamente moderno -según indica Yurkievich-, surgido de la necesidad de búsqueda pero también de un profundo estado de duda que imposibilita el cumplimiento de esa búsqueda. Por lo tanto, convendrá distinguir entre un misticismo inmanente a la persona, que habrá alcanzado ya dicho absoluto más allá del éxito o fracaso de la labor creativa, y un misticismo comprendido como orientación hacia un absoluto de origen divino, precedido sin embargo por la falta de certezas. Valente participa, sin duda, de la segunda de estas posibilidades, pues su estética se presenta no como espejo de la divinidad sino como interrogación, como camino truncado en pos del absoluto.

El elemento motor que guía a nuestro poeta se corresponderá con la duda, con un estado de necesidad y no, en cambio, con una seguridad desde la que el camino hacia ese espacio abisal resulta ufano o al menos nada desgarrado. Dicho terreno abisal, en la obra de nuestro autor, se ofrecerá como un margen en movimiento que continuamente habrá de rebasarse, apuntando, en última instancia, hacia un más allá de imposible resolución en tanto que la carencia de certezas radica en el interior del poeta. Así, todas aquellas barreras intermedias entre el sujeto y el objeto, todos los velos de maya levantados entre ambos serán proporcionales a las dudas internas, tornándose aquéllos no ya en ventanas hacia la divinidad sino en muros sucesivos e infinitos dada su incapacidad de traspasar un ámbito cuya amplitud converge con la 
incredulidad que erige todos aquellos límites grisáceos que el sujeto atraviesa en su camino.

Helena Antolin Cochrane, estudiosa de la obra de Valente, tras afirmar que "el hablante determina perseguir algo imprecisable que está fuera de su alcance, y el poema refleja tal determinación, guiada a cada instante por la intuición más que por el conocimiento de que se puede satisfacer el impulso del hablante" (132), indicará que

la frustración del protagonista aumenta cuando reconoce que no es posible trascender los límites que su restringido conocimiento de las palabras con sus múltiples secretos imponen. El lenguaje del amor se convierte en el de la destrucción sin sentido porque el hombre está encerrado, aislado por las palabras que trastocan todos sus intereses (178).

Esta imposibilidad, según venimos indicando, no estará determinada por el lenguaje sino por una falta de convicción interna, dado que esta última es la que podría dotar de sentido a la voz del poeta. Una identificación absoluta, por otra parte, entre la realidad y lo expresado no podrá existir al margen del fenómeno espiritual, pues el lenguaje actuará a modo de bisagra que permite despegarnos del objeto, de su forma concreta, para acercarnos a la idea, cuya cohesión última demandará el aludido sentimiento religioso. Este motivo será el expuesto por Rudolf Otto cuando indique que "allí donde 'alienta' el espíritu, las palabras racionales de que se vale la predicación, aunque tomadas en su mayoría de la vida general del sentimiento, son suficientes y eficaces para afinar en seguida el alma en tono justo" (88). En consecuencia, no habrá de cargarse sobre el lenguaje algo que no le concierne y que no está dentro de su naturaleza. Sí, en cambio, recaerá sobre el espíritu humano el darle o no darle un sentido trascendente a ese mismo lenguaje, a esa realidad. Esta tarea, si cabe, será un constituyente básico de su misma esencia. El lenguaje, por todo ello, se mostrará capaz de reflejar experiencias no racionales, quedando la absoluta adecuación entre lo dicho y lo designado en manos de la particular convicción individual.

Indica Kitaró Nishida que "lo que debe ser negado no es propiamente la intuición, sino sólo aquello que el sentido común tiene de opinión" (107), pues, dada su particular relación con el razonamiento, la opinión demandará proposiciones lógicas para dar por válido un contenido, un lenguaje, cuya veracidad tan solo requerirá del libre vuelo de su impulso más natural y elevado, el simbólico-poético. 
Cabe recordar en este punto la afirmación de Frithjof Schuon concerniente a que

l'art, dès qu'il n'est plus déterminé, illuminé, guidé par la spiritualité, est à la merci des ressources individuelles et puremente psychiques des artistes, et ces resources doivent s'épuiser en raison même de la platitude du principe naturaliste qui ne veut qu'un décalque de la nature visible [...]. Le naturalisme, en effet, est véritablement luciférien avec son intention d'imiter les créations de Dieu, sans parler de son affirmation du psychique au détriment du spirituel, ou de l'individuel au détriment de l'universel ; il faudrait sourtout dire aussi: du fait brut au détriment du symbole. Normalement l'homme doit imiter l'acte créateur, non la chose créée; C'est ce que fait l'art symboliste, et il en résulte des "créations" qui, loin de faire double emploi avec celles de Dieu, les reflètent conformément à une analogie réelle, et révèlent les aspects trascendents des choses ; c'est en cela que consiste la raison suffisante de l'art, abstraction faite de l'utilité pratique de ses objet (98-99).

Dada su naturaleza simbólica, el lenguaje se presentará como elemento adecuado para denotar un objeto trascendental, siendo la expresión, del mismo modo que el resto de realidades palpables, en mayor o menor medida denotativa de un orden superior en función de una espiritualidad que no procede solo de las palabras sino, por supuesto, y en primer lugar, del creador o incluso, en obras maleables dada su naturaleza abierta, de quien se acerque a la obra como receptor.

\section{EL ESPÍRITU SIMBÓLICO DE LA CREACIÓN}

Con lo recién mencionado, podemos afirmar que no cabe hablar de símbolo si no va acompañado de un sentido trascendente en constante potencialidad expansiva, permanentemente asociado, por lo tanto, a un proceso de metamorfosis individual. En los momentos en que este espíritu no se observe convendría mejor hablar de alegoría ${ }^{3}$. En cualquier caso, nada resultará más

3 La comprensión de la alegoría como símbolo cosificado, considerado como modelo de representación de un poder, es estudiada y explicada por Juan Eduardo Cirlot, quien en su Diccionario de símbolos indicará que las alegorías

aunque no son símbolos, se basan en cierto material simbólico, o lo incluyen, y pueden tener repentinas "resurrecciones" desde su pétrea situación de semiverdades. Se ha 
eficaz que el lenguaje, de acuerdo con su flexibilidad consustancial, para dar cabida al sentido mítico y, con ello, al religioso, que permanecerá arraigado a la esfera del individuo. El descondicionamiento habitual propuesto por José Ángel Valente irá encaminado a despojar al lenguaje de los elementos no simbólicos, a desligarlo de cuanto ya no se muestra como organismo vivo de la creación. Ahora bien, lo simbólico no se manifestará de modo directo, sino mediante un acto interior que aunará cuerpo sensible con realidad espiritual, lo que requerirá de un ejercicio de intuición. Una vez despojado el universo de sus formas alegóricas, escleróticas, surgirá un vacío, un espacio generado que contendrá en su seno el objeto buscado o no contendrá nada. De forma paralela, el objeto indefinido continuará mostrándose como inobservable de no mediar en un momento determinado un salto cualitativo, origen de todo sentido ya en la órbita de lo sagrado. Por consiguiente, el que Valente afirme que el yo "ha de vaciarse de sí, hacerse solo hueco o nada o vacío, para ser lleno” (Obras Completas II 1341), no implicará una mayor gravidez espiritual por parte del individuo, pues lo lleno o lo vacío, sin más, no resultará indicio de cualidad sino de cantidad, competiendo tan solo al orden anímico de aquel la presencia o no de hálito religioso, el cual perfectamente podrá remitirnos tanto a un estéril nihilismo como a una plenitud espiritual capaz de recorrer de principio a fin todo cuanto se pone de manifiesto sobre la obra.

Según comentamos, no podremos observar en la obra de Valente una certeza sobre el significado de esta nada, estableciendo su mayor o menor aproximación a lo religioso, como mucho, en función de la radicalidad con que se emprende una búsqueda llevada a cabo, en cualquier caso, al margen de toda convicción interna. Esta búsqueda ciega llevará al poeta a hipertrofiar sus propios límites participando así de una tirantez existencial más desgarrada a medida que se acentúa el distanciamiento, toda vez que es en el interior, en la contención, donde descansa la sustancia que permitiría el sosiego de su poesía, no en un exterior ilimitado e infinito manifestado a modo de reflejo

dicho que el símbolo da la imagen (y la emoción) de una forma superior de realidad, mientras la alegoría, por el contrario, materializa -aunque sea estéticamente- ideas abstractas, virtudes, etc., de modo más bien convencional. La alegoría se hallaría, en el extremo opuesto, en situación parecida a la del signo convencional, con respecto al símbolo, [que] está en la vida que puede ponerse en movimiento por el contacto del espíritu con esas obras, mejor que en ellas mismas, pues son iconografía, en realidad (Cirlot 76-77). 
de su yo, narcisismo cósmico abocado al distanciamiento absoluto entre uno y otro polo poético.

El decir, la palabra definitiva quedará, según vemos, como promesa incumplida puesto que no se aprehenderá el objeto último de su cosmos. El sujeto lírico habitará de este modo estancia tras estancia, imagen tras imagen, surcando la amplitud del universo poético sin llegar, para su desamparo, a una certera revelación. La búsqueda quedará de antemano entregada a los brazos de una divinidad escondida. El cosmos intermedio resultará rechazado mientras el fin último convergerá con un principio desprovisto de significación trascendente: el rostro de esa nada no se habrá de descifrar. Señala al respecto el autor que

ha de engendrar el poema un vacío, no un pleno. Y así nos invita a su interior. Rechazo, pues, de excedentes verbales y del uso pertinaz de la palabra como multiplicador de la trivialidad. Eje vertical, eje de un tiempo suspendido, no acabado, el poema remite al silencio como forma natural de su duración: silencio incoativo, en el que la misma "suspensión del lenguaje" sería la absoluta inminencia del decir (Valente, Obras Completas II 1334),

instante previo a la formación, "punto donde comienza la respiración, donde el alef oblicuo entra como intacto relámpago en la sangre” (Valente, Obras Completas I 397). Será en este estado larvario donde resida el hálito que, a partir de entonces, se irá perdiendo conforme la materialización de la energía desplace su sentido de lo no visible hacia lo manifiesto.

\section{LA PALABRA COMO POSIBILIDAD DE APERTURA}

La forma, la expresión poética, como vemos, poseerá la capacidad de actuar a modo de celda del hálito creador, al tiempo que la de ser comprendida como hogar, como morada que permitirá la concreción de ese mismo hálito. Desde esta creencia, indica Heidegger:

Lo que hay de cósico en la obra no se debe negar. Pero esto cósico en la obra, precisamente si pertenece al ser obra de la obra, debe ser pensado desde lo que tiene de obra la obra. Si es así, entonces el camino para determinar la realidad cósica de la obra no va de la cosa hacia la obra, sino al contrario, de la obra a la cosa (Carta 60). 
En este caso, el mundo fenoménico ya no es cerrazón al mundo del espíritu sino apertura, forma dinámica llamada a vivificar lo real. "La obra de arte abre a su modo el ser del ente. Esta apertura, es decir, el desentrañar la verdad del ente, acontece en la obra. En la obra de arte se ha puesto en operación la verdad” (Heidegger, Carta 60). Así, la obra solo abrirá su espíritu al mundo cuando surja como realización directa del ser, combatiéndose la mecanización mediante la contemplación del fenómeno. Cada una de las partes de la obra, a su vez, cobrará sentido orgánico en el momento en que se comprenda en función de un todo expuesto a múltiples variaciones, mientras que lo único que debe permanecer fuertemente cerrado es el puño con que el poeta concentra el aliento espiritual. Una desconfianza en la parte no será sino síntoma de un escepticismo ante una totalidad que el poeta no podrá jamás alcanzar, pues lo vacío, como lo absolutamente pleno, escapa no solo a la manifestación sino a la convicción de quien no ve en lo sencillo la materia en constante formación como parte de una totalidad.

La fuerza del sentimiento religioso -señala Ruskin-, es capaz de suministrar por sí misma todo lo que está ausente en las sugerencias más toscas del arte, como también es capaz, por un lado, de purificar lo grosero y volverlo inofensivo, y por el otro, de intensificar lo débil y volverlo impresionante (17).

Por ello, los silencios o vacíos de la obra, cuando ésta permanece despojada de sentido religioso, no gozarán de mayor concentración sagrada que las formas materializadas, mientras que, al contrario, la participación de lo divino en la creación hará de la materia un componente tan sumamente sacro como el manifestado por el silencio. Por todo ello, podemos decir que el libre desarrollo del espíritu creativo se expandirá ya a través del vacío, ya a través de la materia, no siendo propiamente ni el vacío ni esa materia definitorios de la presencia o de la ausencia del componente sacro de la realización, pues su orden sagrado devendrá exclusivamente, como ya mencionamos, de la espiritualidad con que nace en el creador y es asimilada por el receptor.

En cualquier caso, Valente, en la medida en que desconoce el fin ulterior de su realización, su sentido y su fundamento, se entregará a crear lugares desocupados con la esperanza de que en estos solitarios parajes acontezca la epifanía, quedando la creación como lugar propicio para la entrada de lo sagrado pero - dada su oscuridad anímica-, resultando habitada finalmente por la duda. El poeta, por lo tanto, no podrá compartir la idea de una totalidad anterior a una forma que va incesantemente ampliándose, por lo que quedará 
condenado a una errante búsqueda en pos de un absoluto situado siempre más allá de la expresión, sin término alguno, columna sin fin entregada a la indeterminación.

En consecuencia, así como el vacío o el silencio no implican, ni mucho menos, unidad lograda -ni siquiera descondicionamiento-, la forma, del mismo modo, no irá acompañada de un sentido predispuesto de antemano. El descondicionamiento habrá de operarse al tiempo que se tiene conocimiento del sentido claro hacia el que se quiere llegar, ni antes ni después, quedando repartido el sentido de lo expresado entre la oscuridad, la sombra que a su paso va dejando la historia, y la luz, siendo esta última la que, sin necesidad de alcanzar fin alguno, nos muestra de manera constante dónde reside lo verdaderamente vivo y eterno de la creación. El conocimiento surgirá al tiempo que se realiza la obra. Por ello, según Valente, la verdadera creación exige que no se dé un sentido decidido de antemano; el vacío posibilitará este desconocimiento necesario para la libre formación de la obra. De igual manera, se rechazará una totalidad preexistente a cada formación en la medida en que no existe un sentido firme y consolidado ulterior a la misma. Por ello, la creación quedará anudada a un terreno firme únicamente por medio de la raíz, pero no ya por medio de su fin último, pues éste permanecerá completamente desconocido, lo que supondrá la ruptura entre un sentido inicial y un desarrollo final. Precisamente en este aspecto, por derivación, podemos apreciar el rechazo hacia todo acercamiento entre un marco ahistórico y un desarrollo histórico de la creación. La parte existe tan solo por un instante para posteriormente desvanecerse. La historia es para el poeta una caída, caída que apunta finalmente hacia la destrucción de lo creado, hacia un nuevo y reiterado grado cero de escritura.

\section{POESÍA, POETA Y VACÍO}

La reunión entre sujeto y objeto cerrará el círculo de la obra, dejando en dichas ocasiones una creación completa y acabada, no pudiendo decirse lo mismo de la vivencia religiosa, una vez que no se asiste al hallazgo de la divinidad que tanto se ha buscado. Así, cuanto en la realización estética se nos muestra como un logro, como un clímax, en el interior del poeta se comprende como fulgor del que apenas quedarán sus cenizas, lo que obligará al creador, progresivamente más desanimado, más furioso, a emprender nuevamente el trayecto en pos de un incierto instante de plenitud: 


\section{VACÍO}

No tener,

no sentir el calor de tu cuerpo.

ESTE tiempo vacío, blanco, extenso, su lenta progresión hacia la sombra.

No se oye la voz.

No canta.

$\mathrm{Ni}$ engendra una figura otra figura.

Ni vuela un pájaro.

Se esconde

en los oscuros pliegues de la noche.

No viene a mí la luz como solía.

No me despierta a más ventura el aire

para solo seguir su largo vuelo.

No hay antes ni después.

Andamos para nunca llegar,

oh nunca, adónde.

Me detengo

(Valente, Obras Completas I 580-581).

Este vacío o sombra no poseerá, como podemos ver, un sentido de completitud, de confianza alcanzada por medio de la búsqueda. No asistimos a una concentración de absoluto, de nada mística, sino a una oscuridad temerosa y desoladora donde residen "jueces tributarios de sombra / y sombra / y sombra” (Valente, Obras Completas I 581).

Como hemos indicado, las fulgurantes reuniones entre creación y creador no podrán comprenderse a modo de feliz casamiento entre Dios y su criatura, al no implicar la realización de esta unión en un plano trascendental. Queda así el sentido último de la obra tan oscuro y gris como al comienzo la encontramos, afirmándose la palabra pero no así la naturaleza sagrada del ámbito en que ésta acontecerá. Nada seguro ni permanente nos será mostrado: "Efímera / construyo mi morada” (Valente, Obras Completas I 581). El vacío quedará como un espacio desconocido; ni rastro de los dioses, ni rastro de uno mismo. El tiempo de la posesión se agota y la creación ha atravesado al poeta sin dejarle más que breves instantes de luz y oscuridad, fugitivos, de paso, sin un poso de certeza que logre calmar su inquietud.

Puesto que nada quedará ya de los dioses, afán de absoluto perdido en pleno vuelo, Antonio García Berrio hará referencia a un "misticismo [...] 
moderno de Valente: rayo de oscuridad, fondo espeso de ceros sin resquicio de luz, chapoteo de la nada, débiles ecos sin imagen alguna, sin regalo por siempre de dulzura; dolor de decir solo, mística abstracta" (2). El decir se agotará en sí mismo en el momento en que se desconfía de aquella totalidad capaz de contener la palabra, dudándose del objeto hacia el que apunta la voz en su deseo de trascenderse, de designar, de tornarse en fuerza multiplicadora de luz y de sentido. Como bien indica Díaz Gamboa, "en la sombra de los límites se presagia una fuga y un retorno; se sale del lenguaje para entrar en él" (599). No habrá un más allá del lenguaje en la medida en que cuanto sale de su cuerpo -que a su vez se muestra como cárcel- se adentrará en un espacio brumoso propicio para la desorientación, una salida hacia la infinita niebla imposible de penetrar, saliendo de una celda para entrar en otra de más vastas e informes medidas. El silencio, como el vacío, precede y espera más allá de la palabra, no pudiéndose sino hablar desde la inminente distancia, apuntándose siempre un poco más allá de cuanto se expresa para realizar de nuevo la misma acción en el momento en que tal enclave ha sido conquistado. El silencio se convertirá en el componente esencial de este verbo carente de morada.

El devenir del que participa la poesía de José Ángel Valente se encuentra separado de un espacio al que no tendrá acceso el verbo. Existencia y esencia, salvo en contadas excepciones, se manifestarán por ello como espacios de imposible reunión, permaneciendo el poeta en un peregrinaje cósmico que le llevará de una orilla a otra de la creación sin poder alcanzar una verdad, una certeza en la que descansar. Menciona Eduardo García:

Encontramos en la obra de Valente un continuo girar en torno al centro ausente, un inquieto merodear en el vacío. Tales son las obsesiones de su mística sin Dios: el vacío, la nada, el centro, el agujero o hueco, el túnel, lo oscuro, el desierto, el no. Y en idéntica dirección operan sus continuas referencias a la ausencia o, más explícitamente a la muerte (293).

Como experiencia religiosa con ansias de totalidad, la poesía de Valente no logra más que un agrandar más y más el conflicto irresuelto con el que comenzó su andadura, un conflicto manifestado a través de dilogías en escasos momentos unificadas, situadas unas en un orden existencial y las otras en un mundo de esencias lejano a cuanto es capaz de comprender el intelecto.

El apego hacia el vacío será indicio de una honda espiritualidad, y a su vez de una imposibilidad de satisfacer esa misma sed espiritual, al no 
producirse un asentamiento del verbo sobre certeza alguna. Dicho apego constituirá, en cambio, una forma lograda en la poesía del autor, un estado espiritual convertido en modelo de una creación que dominará cierto espectro de nuestras letras hasta hoy día. Eduardo García indicará poco después del anterior comentario, en lo concerniente a lo fallido de la búsqueda de un absoluto trascendental, que

no sospechaba Valente que esa fantasía de refugio matricial tan solo es engendradora de vida si nos disponemos a atravesarla para salir a la luz. A la inversa de lo que le sugería su melancólica inclinación, era precisamente fuera de la matriz donde le aguardaba la vida, mientras sólo la muerte, la inmovilidad, podría alentar en el umbrío huevo de la madre. Soñando protegerse del afuera renunciaba a la transformación. [...] Sin embargo, refugiarse en la fantasía del retorno al origen significa permanecer en la inmanencia o la proximidad de la germinación... para nunca germinar. Permanecer siempre frente al umbral, mientras la vida fluye, crea, fructifica al otro lado. El precio, pues, de la paz interior, del sereno transcurso de esta poesía histérica, es la renuncia. En su mundo no hay lugar para la fractura del yo, pero tampoco para el deseo, la exaltación de la vida, la persecución de los sueños. Habitamos aquí la desolación de lo que nunca alcanza a despertar. Un espacio para la disolución del sujeto, la atormentada paz de la renuncia. Y sin embargo, en algunos tan escasos como palpitantes poemas, Valente parece vislumbrar la salida de la gruta. Es ahí donde descubrimos al poeta que pudo ser, así como, al que habiéndonos revelado tan vasto territorio, permaneció en el umbral del poeta venidero (296-297).

El creador parece, efectivamente, encontrarse lejos de la zona luminosa de la realidad, aproximándose por momentos hacia ella para luego dejarse otra vez arrastrar hacia la sombra, hacia un gris imposible de ser disipado. El poema se desarrollará en "la más absoluta interioridad. Interior intimo meo: más interior que lo más íntimo de mí” (Valente, Obras Completas II 1388), dando la sensación de no poder elevarse hacia un terreno de certera definición. De esta manera, según nos recuerda Díaz Gamboa, Valente

nos muestra palabras medio borradas que están continuamente oscilando entre el anverso y el revés, en el umbral de un entorno de realidad en el que sólo subsisten las mediaciones, graduaciones y mixturas para las cuales sólo parece ser apropiada una lógica afín a los fenómenos de cambio dentro de un continuo general (292); 
palabras no totalmente desplegadas, siempre cohibidas, siempre un poco acá y un poco allá, a modo de pliegue que "comprende lo indecible, el movimiento entre dos silencios. Presente ausente, el doblez que al desdoblarse se oculta" (Díaz Gamboa 1496); palabras lejanas ya de la seguridad que les otorga el contacto con la materia, el reposo en el interior de la mandorla, tal y como acontece en un periodo central de la creación del orensano.

Asistimos en todo ello, en este ir y venir del mundo material al inmaterial, a un proceso de descarne de la materia, del Logos, del tiempo, al que se pretenderá despojar de una dimensión histórica. En este recorrido incesante aguarda la naturaleza trágica de la obra, aquella que impone sobre el poeta una necesidad abismal y lo atrae hacia sus brazos. En función de este desaforado indagar y el fracaso de no alcanzar el objeto de deseo, la sensación de soledad quedará acentuada ofreciendo la impresión de que, tras la palabra, no aguarda nada ya. El ser permanecerá recluido en su interior, en su centro descentrado, subrayando de este trágico modo la vacuidad que conforma la individualidad del poeta.

Según menciona Ernst Bloch, “en el surgir de algo hay todavía algo que queda atrás. Es un elemento crepuscular que se da siempre, y que no se libera totalmente de este 'no', de este 'no aquí' en la proximidad inmediata del acontecer" (234). El crepúsculo, con un pie en la noche y otro en la mañana, emergerá como símbolo de indeterminación. No habrá representación final, no habrá fuerza excéntrica que impulse con rabia la materia hacia la luz, hacia la realización del objeto. El poema se desarrollará a modo de tanteo, de atisbo nunca afianzado en tanto que permanentemente abierto, dibujando una serie de claroscuros pero ni un solo contorno sólido que afiance y dote de sentido a lo real. Según podemos ver en aquellos momentos en que asistimos al surgimiento de la forma, ésta quedará como algo provisional una vez que tenderá a constituirse en objeto sólido y apto para el asentamiento del poder; en elemento, en consecuencia, a erradicar por parte del poeta, quien indicará que "La forma en su plenitud apunta infinitamente hacia lo informe. La última significación de la forma es su nostalgia de disolución, de reinmersión en lo amorfo" (Valente, Obras Completas II 463). La forma, según señalará Valente, tenderá hacia su propia abolición al no ser parte consustancial de la voluntad creadora, sino velo de maya, manifestación falsa y engañosa.

En la obra de Valente, tan solo la concurrencia de símbolos amplios y consagrados, el surgimiento de ejes axiales, árbol u hombre, propiciará la aparición de aquellas únicas imágenes de su poesía donde lo humano y lo divino se manifiestan de modo integrado. Se mostrarán entonces efervescentes 
imágenes dadas al deseo, entregadas a un mundo dotado de formas, a una rica y vivificadora diversidad. En la materia encontrará Valente su más poderosa plenitud espiritual, contrariamente a lo observado en el mundo deshabitado al que tanto acudirá en busca de un Dios. En esos terrenos nebulosos no encontraremos claridad ni imágenes permanentes, no hallaremos contornos precisos; sí, en cambio, leves indicios de transparencia, pero con esta cualidad no se consolida sino que se anulará la forma del objeto.

\section{EL TEMPLO DE LA CREACIÓN ESTÉTICA}

La permanencia, por lo tanto, en el reino de lo formativo, acercará a Valente a una identificación de la poesía con el enigma, con Loxias, no afirmando ni negando, sino únicamente manifestando un decir en ocasiones vago, en ocasiones certero, y siempre en continuo rehacimiento. La carencia de un sentido, de un fin claro hacia el que elevar la mirada, la permanencia dentro de una rueda giratoria en la que todo, tras resultar brevemente realizado, pasa de nuevo a quedar disuelto, es la tónica general de la poesía que nos ocupa, rica en insinuaciones pero escasa en manifestaciones definitivas. Su poesía se inserta, por momentos, en la vida como manifestación irracional, como carencia de destino entregada a los caprichos de no se sabe quién, arrastrando al hombre de aquí para allá y obligándole, en su desesperación, a crearse un sentido, algo que el autor querrá evitar una vez que, como manifestación de lo vivo, el poema rechazará la forma aceptando tan solo la formación, la continua transformación del espíritu creador. La palabra habrá de desproveerse de solidez con el fin de alcanzar su fondo espiritual, entrándose así, de lleno, en el terreno de la expresión mística:

Pide esa palabra el dejamiento del sentido para poder entrar "adentro en la espesura" o en la oscuridad del rayo de tiniebla. [...] Sin embargo, la revelación del espíritu sólo es posible en la medida en que está encerrado en la letra y ésta en tensión de terrible alumbramiento de lo que dentro de sí tiene y, a la vez, no puede contener (Valente, Obras Completas II 397).

Como vemos, la letra alberga pero, por otra parte, aprisiona el espíritu de la palabra, su fuerza vital, arremetiendo entonces el poeta contra toda solidez al considerarla equivocada. De acuerdo con Caillois, "el que se atreve a poner en movimiento las fuerzas subterráneas, el que se abandona a las potencias 
aquerónticas es el que no se ha contentado con su suerte" (60). Este hombre es el poeta, el no usurpador, el no poseedor y no participante en el uso de un lenguaje que no le interesa en tanto que formado y, por ello, cosificado.

Señala Robert Langbaum que

existe un tipo de jerarquía existencial merced al cual el hablante se justifica, no porque tenga más razón que otros personajes -rara vez la tiene- sino porque está más vivo que ellos [...] Se trata del único personaje cuya caracterización es lírica y, por lo tanto, del único personaje que conocemos desde dentro -en cuyo seno sentimos el pulso de una vida como la nuestra, por la sencilla razón de que su vida no deriva tanto de la situación cuanto de un caudal de existencia que nosotros suministramos (328).

La realización, la finitud, no existirá para el poeta, que en palabras de Juan Eduardo Cirlot "es sólo alguien que responde a preguntas formuladas por algo que se asemeja extrañamente a la nada. Y su voz tiene resonancias que él no podría evitar, aunque quisiera" (599). Este poeta de los abismos es el habitante de la nada, silencioso chamán sumergido en las aguas de la creación. Desde ellas observa y, en ocasiones, dejará desprender una parte de sí, un algo de su ser, una voz como sedimento que escapa a la corriente y se eleva hacia la superficie, hacia la manifestación. El creador se adentra en la materia engendradora y se va a refugiar en su seno, en la mandorla, eje axial desde donde nada interrumpirá su mirar prístino, sin alterar cuanto apenas le roza, sin determinar nada en absoluto, sin tan siquiera realizar una opinión sobre cuanto ocurre frente a él, limitándose simplemente a contemplar.

Como guardián del lenguaje, tal y como lo considera Heidegger ${ }^{4}$, el poeta toma de aquél cuanto permite su germinación. La forma en sí, la voz poética, será un recuerdo de aquello que poseía sentido bajo la superficie. Al respecto, María Zambrano señalará que

\footnotetext{
"El pensar lleva a cabo la relación del ser con la esencia del hombre. No hace ni produce esta relación. El pensar se limita a ofrecérsela al ser como aquello que a él mismo le ha sido dado por el ser. Este ofrecer consiste en que en el pensar el ser llega al lenguaje. El lenguaje es la casa del ser. En su morada habita el hombre. Los pensadores y poetas son los guardianes de esa morada. Su guarda consiste en llevar a cabo la manifestación del ser, en la medida en que, mediante su decir, ellos la llevan al lenguaje y allí la custodian” (Heidegger, Carta 11-12).
} 
el poeta no toma jamás una decisión, es cierto. El poeta soporta únicamente este vivir errabundo y como sin asidero. Soporta el vivir instante a instante, pendiente de otro a quien ni siquiera conoce. Entrevee algo en la niebla y a esto que entrevee es fiel hasta la muerte, fiel de por vida. Y no le exige, como el filósofo, ver su cara para entregarse a él (45).

En consecuencia, el poeta participa de la creación misma, de un mundo anterior a la concepción convencional del lenguaje. El creador, en un primer acercamiento al lenguaje, tomará la palabra directamente de la materia: "En algún momento he pensado que solamente es poeta el que llega a tener una relación carnal con las palabras. La palabra, la materia, el cuerpo del amor, el cuerpo del mundo son una sola y la misma cosa” (Valente, Obras Completas I 1439). Así, lo que para el individuo de la superficie se muestra como separación, para el poeta se abre como unión con la voluntad del mundo, una permanencia en sus verdaderas fuentes, en su vivencia directa, en su no significación. El vacío de esta voluntad, el silencio, se erige como lugar de obligada transición antes de que la forma estalle definitivamente haciendo acto de aparición para finalmente perderse mucho más allá de la superficie, de una superficie comprendida por el poeta como engaño, como espacio donde no podrá habitar lo poético puesto que toda medida, orden y exactitud no dejarán margen para un latido que apenas se escucha ya, una pulsión de la que apenas oímos su apagamiento pues vivimos en exceso distantes del verbo creador, lejanos del ritmo poderoso de un cosmos en permanente ebullición.

La poesía compete tanto a la manifestación como a cuanto la precede. Por ello, Montale, tan cercano a nuestro poeta tanto en su modo de sentir como de expresarse, escribirá:

pienso que ésta [la poesía] nació de la necesidad de añadir un sonido vocal (la palabra) al martilleo de las primeras músicas tribales. Sólo mucho más tarde la palabra y la música pudieron escribirse y diferenciarse. Aparece la poesía escrita pero se siente el parentesco común con la música (12).

Desde este lugar abismal, desde este fondo, surgirá la poesía de José Ángel Valente entregada al silencio, al vacío, aunque a su vez partícipe en no pocos periodos creativos de su trayectoria de una riqueza material viva y abundante. De estos vastos dominios hollados por el poeta se alzará un silencio que incidirá con fuerza sobre generaciones posteriores. Al respecto Sánchez Santiago señalará: 
Este Valente [... ] era considerado el iniciador efectivo de una corriente poética, demasiado en boga en la actualidad, que se ha englobado bajo el denominador común de "poética o retórica del silencio” [...] Nace aquí una de las falacias más graves que ha vivido parte de la poesía española contemporánea. Falacia que ha servido y sirve de cobijo a una abundante producción poética obsoleta de raíz, muerta en su propia inutilidad, que no dice nada no por imperativo del silencio como magma poético, sino porque nada tiene que decir, amparada en la moda y no en la esencia, ejerciendo un magisterio tremendamente negativo sobre poetas pretendidos que, antes que a escribir, aprenden a callar (344).

Con ello queda de manifiesto una vez más que cuanto se tiende a copiar es aquello que resulta fácil de ser adueñado, en este caso no la calidad formal o la hondura simbólica, sino la puerta por donde entran y salen voces sin que resulte necesario ampliar su marco: el vacío, el silencio, elemento básico en la obra de nuestro autor pero no representativo, ni mucho menos, de la amplitud de su vasto espectro.

Según todo cuanto hemos ido observando, este vacío, esta nada, se comprende como límite de la creación, preexistiendo y posibilitando que la voz estalle, dando lugar a una primera manifestación al tiempo que determinando el sentido último de ésta en la medida en que el objeto último carece de finitud, de corporeidad. Entre uno y otro extremo, a cada expresión lograda, a cada afirmación o negación, le sucederá un acto de vaciamiento, un devolver la escritura a su grado cero, presentándose ante nuestra mirada un espacio absolutamente ilimitado, inmenso templo de dolor en tanto que el dios no acudirá al centro, en tanto que no podrá quedar cerrada una bóveda a cada instante más amplia, más desolada también, pues todo hecho luminoso, todos aquellos momentos de certeza, son despedazados quedando frente a nosotros un cosmos oscuro e incierto, un universo imaginario conformado por miles de bellos cristales esparcidos en la infinitud del firmamento.

\section{BIBLIOGRAFÍA}

Bloch, Ernst. El principio esperanza, I. Madrid: Trotta, 2007.

Caillois, Roger. El hombre y lo sagrado. México: Fondo de Cultura Económica, 1996.

Cirlot, Juan Eduardo. Diccionario de símbolos. Madrid: Siruela, 2011.

Cochrane, Helena Antolín. "El ideal de perduración a través de la palabra poética en la poesía del 50 en España: Ángel González, José Ángel Valente, Jaime Gil de Biedma”. Dissertation Abstracts International 52.3 (1991): 937. 
Díaz Gamboa, Sandra Lucía. "La experiencia de los límites en la obra de José Ángel Valente y sus implicaciones lógico-matemáticas”. UNED, 2009.

Gamoneda, Antonio. Valente: texto y contexto. Santiago de Compostela: Universidade da Santiago de Compostela, 2007.

García, Eduardo. “José Ángel Valente: el refugio-matriz o la tentación del vacío”. Pájaros raíces. En torno a José Ángel Valente. Eds. Marta Agudo y Jordi Doce. Madrid: Abada, 2010. 289-298.

García Berrio, Antonio. “Valente: Descensos antiguos a la memoria”. Ínsula 570-571 (1994) $1-2$ y $27-28$.

Heidegger, Martin. Carta sobre el humanismo. Madrid: Alianza, 2001.

Ser y tiempo. Madrid: Trotta, 2006.

Jung, Carl Gustav. Sobre el fenómeno del espíritu en el arte y en la ciencia. Madrid: Trotta, 2002.

Lacalle Ciordia, Ma Ángeles. La poética de José Ángel Valente. Pamplona: Gobierno de Navarra, 2000.

Langbaum, Robert. La poesía de la experiencia. Granada: Comares, 1996.

Montale, Eugenio. Sobre la poesía. México: Universidad Autónoma de México, 2000.

Nishida, Kitaró. Pensar desde la nada. Salamanca: Sígueme, 2006.

Otto, Rudolf. Lo santo. Madrid: Alianza editorial, 2009.

Pareyson, Luigi. Conversaciones de estética. Madrid: Visor, 1988.

Peinado Elliot, Carlos. Unidad y trascendencia. Estudio sobre la obra de José Ángel Valente. Sevilla: Alfar, 2002.

Ruskin, John. Las piedras de Venecia. Murcia: Consejo General de la Arquitectura Técnica de España, 2000.

Sánchez Robayna, Andrés. Deseo, imagen, lugar de la palabra. Barcelona: Galaxia Gutemberg, 2008.

Sánchez Santiago, Tomás y José Manuel Diego, eds. Dos poetas de la generación de los 50: Carlos Barral y José Ángel Valente. Granada: Antonio Ubago, 1990.

Schopenhauer, Arthur. El mundo como voluntad y representación, II. Madrid: Trotta, 2009.

Schuon, Frithjof. De l'unité trascendente des religions. Paris: Seuil, 1979.

Trueba Mira, Virginia. “La poética encarnada de José Ángel Valente”. Letras de Deusto. 112.36 (2006): 159-176.

Valente, José Ángel y Nuria Fernández Quesada, eds. Anatomía de la palabra. Madrid: PreTextos, 2000.

Valente, José Ángel. Obras completas I. Poesía y prosa. Barcelona: Galaxia Gutemberg/ Círculo de Lectores, 2006. 2008.

Zambrano, María. Filosofía y poesía. Madrid: Fondo de Cultura Económica, 2006. 